\title{
LAMINECTOMY WITHOUT INSTRUMENTATION FOR SURGICAL TREATMENT OF METASTATIC SPINAL CORD COMPRESSION
}

\author{
LAMINECTOMIA SEM INSTRUMENTACCÃO PARA TRATAMENTO CIRÚRGICO DA \\ COMPRESSÃO MEDULAR METASTÁTICA
}

\section{LAMINECTOMÍA SIN INSTRUMENTACIÓN PARA TRATAMIENTO QUIRÚRGICO DE LA COMPRESIÓN METASTÁSICA DE LA MÉDULA ESPINAL}

Paulo Alvim Borges ${ }^{1}$, William Gemio Jacobsen Teixeira², Douglas Kenul Narazaki², Alexandre Fogaça Cristante ${ }^{2}$, Cesar Salge Ghilardi², Manoel Jacobsen Teixeira ${ }^{3}$, Olavo Pires de Camargo ${ }^{1}$, Tarcisio Eloy Pessoa de Barros Filho ${ }^{1}$

\begin{abstract}
Objective: To analyze the development of mechanical complications as a result of spinal decompression or cauda equina in patients with metastatic tumors of the spine via laminectomy or laminoartrectomy without fixation. Methods: We studied the medical records of all patients submitted to spine decompression with laminectomy without fixation. The decompression was indicated to treat cord compression or cauda equina caused by metastatic tumors. Patients were evaluated for the development of postoperative mechanical instability by comparing the preoperative radiological examinations with the latest one available in the medical record review.. In these images, we evaluated the emergence of new deformity in the sagittal or coronal planes and translational deformity. We consider new deformity, signs of deformity greater or equal to $5^{\circ}$ in the coronal or sagittal planes and signs of increased vertebral translation greater than or equal to $3 \mathrm{~mm}$. Results: No patient developed radiological instability in the period evaluated with an average follow-up of 163.24 days (3-663). The complication rate in our sample was not higher than the previously reported in the literature. Conclusion: Isolated laminectomy at one or more levels is a safe procedure for the treatment of metastatic spinal cord compression where the spine is judged stable before surgery.
\end{abstract}

Keywords: Spinal cord compression; Laminectomy/instrumentation; Spinal neoplasms; Decompression, surgical; Treatment outcome.

\section{RESUMO}

Objetivo: Analisar o desenvolvimento de complicações mecânicas como resultado da descompressão medular ou da cauda equina de pacientes com doença metastática da coluna vertebral através de laminectomia ou laminoartrectomia sem fixação. Métodos: Estudamos todos os prontuários de pacientes que foram submetidos à descompressão da coluna vertebral por laminectomia sem fixação. A descompressão foi indicada por compressão medular ou da cauda equina por tumores sólidos em doença metastática. Os pacientes foram avaliados quanto ao desenvolvimento de instabilidade mecânica pós-operatória através da comparação dos exames radiológicos pré-operatórios com o último exame disponível no prontuário. Nessas imagens, avaliamos o surgimento de deformidade nova no plano sagital ou coronal e deformidade translacional. Consideramos como deformidade nova, sinais de deformidade maior ou igual a $5^{\circ}$ no plano coronal ou sagital e sinais de aumento da translação vertebral maior ou igual a $3 \mathrm{~mm}$. Resultados: Nenhum paciente evoluiu com instabilidade radiológica no período avaliado com tempo médio de seguimento de 163,24 dias (3-663). A taxa de complicações encontrada em nossa amostra não foi superior à encontrada na literatura. Conclusão: A laminectomia isolada em um ou mais níveis é um procedimento seguro para tratamento da compressão medular metastática quando há julgamento de que a coluna é estável no momento da indicação da cirurgia.

Descritores: Compressão da medula espinal; Laminectomia/instrumentação; Neoplasias da coluna vertebral; Descompressão cirúrgica; Resultado de tratamento.

\section{RESUMEN}

Objetivo: Analizar el desarrollo de complicaciones mecánicas como consecuencia de la descompresión espinal o la cauda equina en los pacientes con enfermedad metastásica de la columna vertebral a través de una laminectomía o laminoartrectomia sin fijar. Métodos: Se estudiaron las historias clínicas de todos los pacientes que fueron sometidos a laminectomía sin fijación. La descompresión se indicó por compresión de la médula o la cauda equina por metástasis de tumores sólidos. Los pacientes fueron evaluados para el desarrollo de la inestabilidad mecánica postoperatoria mediante la comparación de los exámenes radiológicos preoperatorios con última imagen disponible en el registro clínico. En estas imágenes, se evalúa la aparición de nueva deformidad en el plano coronal o sagital y deformidad traslacional. Consideramos nueva deformidad, los signos de una deformidad mayor o igual a $5^{\circ}$ en el plano coronal o sagital y signos de aumento de la traslación vertebral superior o igual a $3 \mathrm{~mm}$. Resultados: Ningún paciente desarrolló inestabilidad radiológica en el período evaluado con un seguimiento promedio de 163,24 días (3-663). La tasa de complicaciones en nuestra muestra no era mayor que la encontrada en la literatura. Conclusión: Laminectomía aislada en uno o más niveles es un procedimiento seguro para el tratamiento de compresión metastásica de la médula cuando se juzga que la columna es estable en el momento de la indicación quirúrgica.

Descriptores: Compresión de la médula espinal; Laminectomía/instrumentación; Neoplasias de la columna vertebral; Descompresión quirúrgica; Resultado del tratamiento.

1. Spine Group, Institute of Orthopedics andTraumatology, Hospital das Clínicas da Faculdade de Medicina da Universidade de São Paulo, São Paulo, SP, Brazil.

2. Spine Group, Instituto do Câncer do Estado de São Paulo, São Paulo, SP, Brazil.

3. Department of Neurosurgery, Hospital das Clínicas da Faculdade de Medicina da Universidade de São Paulo, São Paulo, SP, Brazil.

Study conducted at the Instituto do Câncer do Estado de São Paulo, São Paulo, SP, Brazil.

Correspondence: Alexandre Fogaça Cristante. Rua Dr. Ovídio Pires de Campos, 333. Cerqueira César, São Paulo, SP, Brasil. 05416-010. aacristante@uol.com.br 


\section{INTRODUCTION}

Metastatic lesions of the spine are the most common in the skeleton. ${ }^{1}$ They are a frequent cause of pain in patients with cancer. ${ }^{2}$ Other manifestations include neurologic deficits and spinal deformity.

Treatment of metastatic lesions of the spine is still controversial, ${ }^{3,4}$ and its main indications are intractable pain, instability, or neurological deficit. 5,6

In 1980, Young et al. ${ }^{7}$ published a study comparing surgical treatment by laminectomy followed by radiotherapy with radiotherapy alone. They demonstrated that both methods produced the same result. However, the complication rate was higher in the operated group. ${ }^{7}$ As most metastatic lesions occur in the vertebral body, laminectomy promoted the resection of the only intact portion of the vertebra. Besides not treating the instability, it could further aggravate it. A laminectomy would have limitations for obtaining decompression of the spinal cord, since most lesions are anterior to the spinal cord. Thus, there has been reduced use of laminectomy without fixation of the spine due to insufficient decompression and not furthering the treatment of instability. $3,7,8-10$

Studies in the literature ${ }^{8,11}$ indicate that there is a benefit to using spinal fixation. Despite efforts to define objective criteria for judging the instability of spinal metastatic disease, ${ }^{12-14}$ there are still no reliable methods for the clinical practice.

Laminectomy can be an effective form of decompression in patients with metastatic tumors located exclusively in the posterior elements and in those with stable metastatic lesions. Laminectomy without spinal fixation would have the benefit of offering a smaller procedure, reducing the risk of neurological damage, risk of infection, bleeding, and the costs related to the procedure. ${ }^{15}$

This study aims to analyze the results of cauda equina or spinal decompression in patients with metastatic diseases of the spine via laminectomy or laminoarthrectomy without fixation for the development of mechanical complications.

\section{METHODS}

Patients who underwent spinal decompression by laminectomy without fixation in the period between February 2009 and January 2013 were included. All patients had spinal cord or cauda equina compression by metastatic disease and did not undergo spinal fixation in the first surgical treatment of spine. The judgment in the definition of stability in these patients was performed with subjective criteria, through the experience of the surgeon.

Patients who showed the need for fixation of the spine due to mechanical instability or requiring extensive bone resection as a surgical procedure for obtaining decompression were excluded.

Patients were evaluated for the development of postoperative mechanical instability by comparing the preoperative radiological examinations with the latest one available in the medical records. In these images, we evaluated the emergence of new deformities in the sagittal or coronal plane and translational deformity. We consider new deformity to be signs of deformity in the coronal or sagittal plane greater than or equal to $5^{\circ}$ and signs of increase in vertebral translation equal to or greater than $3 \mathrm{~mm}$.

Information regarding gender, age, length of follow-up, oncological diagnosis, prior radiotherapy and Tokuhashi et al. ${ }^{16}$ prognostic scale were obtained. The stability of the lesions was reassessed by using the Spine Instability Neoplastic Score (SINS), ${ }^{13}$ which was applied retrospectively to data from medical records.

With respect to the surgical procedure, we retrieved data on the location of the surgery, duration of the surgery, intraoperative complications, need for and duration of hospitalization in the intensive care unit (ICU), length of hospital stay after surgery and postoperative complications.

\section{RESULTS}

Twenty-one patients, 14 men (66.67\%) and seven (33.33\%) women, underwent laminectomy without fixation. The mean age of the patients was 60.85 years (18.52 to 86.34 ).
The most common location of the primary tumor in this series was the prostate, with 12 cases (57.14\%). Two patients $(9.52 \%)$ had an adenocarcinoma of the colon as the primary tumor. The other patients had as the primary location a tumor of unknown origin, one Ewing's sarcoma with primary location in the femur, one in the breast, one lung adenocarcinoma, one renal clear cell tumor, one papillary thyroid tumor and one in the nasopharynx. (Table 1)

According to the Tokuhashi et $\mathrm{al}^{16}{ }^{16}$ scale, 10 patients (47.62\%) had a total score between zero and eight points, suggesting an expectancy of less than six months survival. Another 10 patients $(47.62 \%)$ had scores between nine and 11 points, with a life expectancy of up to one year. Only one patient (4.76\%) had a score between 12 and 15, with the expectation of more than one year survival. Of the 21 operated patients, seven (33.32\%) had been previously undergone radiotherapy for spinal metastases.

The mean duration of surgery was 124 minutes with a median of 115 minutes. One patient had a prolonged surgery (325 minutes) for having conducted two simultaneous surgeries, laminectomy and resection of brain metastasis.

Regarding the location of the surgical procedure, 10 patients (47.62\%) underwent lumbar laminectomy, eight patients (38.10\%) underwent thoracic laminectomy, two $(9.52 \%)$ in the thoracolumbar transition region, and one (4.76\%) in the lumbosacral transition.

Twelve patients (57.12\%) underwent laminectomy at one level, four patients (19.04\%) at two levels (1\%), three patients $(14.28 \%)$ at three levels, one patient $(4.76 \%)$ at five levels, and one patient $(4.76 \%)$ at seven levels. One patient had a laminectomy extended from one to two levels in a second procedure due to incomplete decompression.

Four patients (19.05\%) had their spines classified as stable by the SINS; 16 patients (76.19\%) with indeterminate stability, and in only one patient $(4.76 \%)$ was the column considered unstable.

No patient developed radiological instability during the study period (Figure 1A, B) with an average follow-up time of 163.24 days (3-663). At the end of the study, nine patients (42.86\%) died, three (14.29\%) were lost to follow-up, and nine were alive and at follow-up. (Table 2)

Two intraoperative complications were recognized. One patient had a lesion of the dural sac that was repaired in the same surgery and one patient had hemorrhaging resulting in hemodynamic instability.

Fifteen postoperative complications were identified in 13 patients (61.9\%). (Table 3 ) Seven patients had infectious complications. Of these, three were urinary tract infection, two were pneumonia, and only one was related to the spinal wound. A patient undergoing spine and skull surgery on the same day developed a skull wound infection. Three patients had a local recurrence. Of

Table 1. Distribution of patients by sex and origin of the primary tumor.

\begin{tabular}{c|c|c|c}
\hline Origin of primary tumor & Male & Female & Overall total \\
\hline Prostate & 12 & 0 & 12 \\
\hline Colon & 0 & 2 & 2 \\
\hline Unknown & 0 & 1 & 1 \\
\hline Ewing's sarcoma & 0 & 1 & 1 \\
\hline Breast & 0 & 1 & 1 \\
\hline Nasopharynx & 0 & 1 & 1 \\
\hline Lung & 0 & 1 & 1 \\
\hline Renal & 1 & 0 & 1 \\
\hline Thyroid & 1 & 0 & 1 \\
\hline Overall total & 14 & 7 & 21 \\
\hline
\end{tabular}




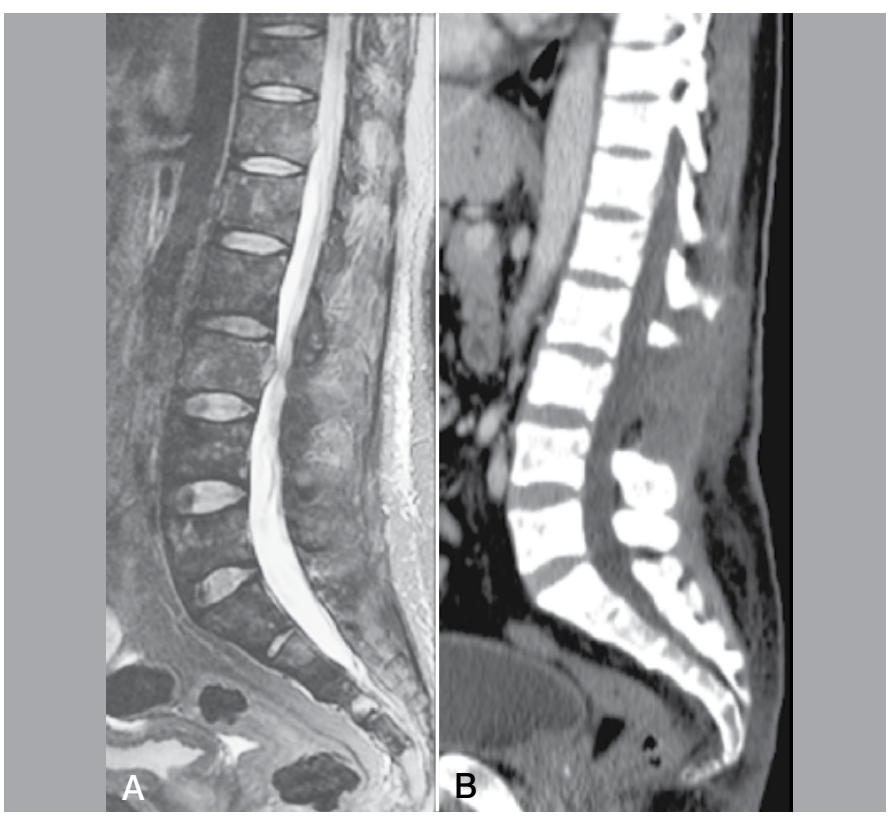

Figure 1. A) Preoperative MRI of a patient with stenosis of the cauda equina by metastatic prostate adenocarcinoma. B) CT scan showing postoperative results with effective decompression and no deformity.

Table 2. Distribution of patient survival and follow-up time in days.

\begin{tabular}{c|c|c}
\hline & $\begin{array}{c}\text { Number of } \\
\text { cases }\end{array}$ & $\begin{array}{c}\text { Mean, minimum, and maximum } \\
\text { follow-up days }\end{array}$ \\
\hline Death & $9(42.86 \%)$ & $68(3-173)$ \\
\hline Alive & $9(42.86 \%)$ & $258(60-663)$ \\
\hline Lost to follow-up & $3(14.29 \%)$ & $164(42-229)$ \\
\hline Total & 21 & $163.24(3-663)$
\end{tabular}

Table 3. Distribution of postoperative complications.

\begin{tabular}{c|c}
\hline Postoperative complications & Number of events \\
\hline Local recurrence & 3 \\
\hline Urinary tract infection & 3 \\
\hline Pneumonia & 2 \\
\hline Late neurological deterioration & 1 \\
\hline Infection of surgical wound & 1 \\
\hline Infection of surgical wound from another simultaneous & 1 \\
\hline surgery & 1 \\
\hline Incomplete decompression with pain maintained & 1 \\
\hline Acute renal insufficiency & 1 \\
\hline Systemic inflammatory response syndrome & 1 \\
\hline Death related to the surgical procedure & \\
\hline
\end{tabular}

these, only one $(4.76 \%)$ showed a worsening of the neurological function due to the absence of adjuvant treatment, and was not related to mechanical complications. (Figure 2) One patient died on the third postoperative day from complications of systemic inflammatory response syndrome.

On average, patients were hospitalized for 9.4 days, with a median of five days (2-43 days). Fourteen patients (66.66\%) required postoperative support in the intensive care unit (ICU) postoperatively, with an average stay of two days (1-3 days).

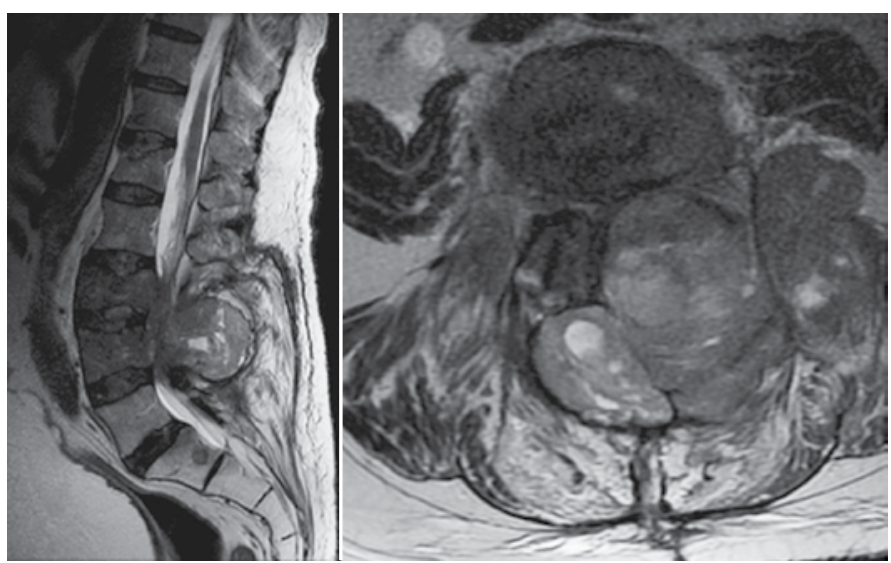

Figure 2. Patients with signs of severe local recurrence with cauda equina syndrome but no worsening of spinal alignment.

\section{DISCUSSION}

Vertebral metastases can cause serious complications such as spinal cord compression, a condition observed in 5 to $14 \%$ of cancer patients throughout the evolution of the disease. ${ }^{8}$ Spinal cord compression may be due to the growth of the tumor in the epidural space or associated with the pathological fracture of the vertebra with compression due to bone fragments or instability secondary to the fracture.

In a randomized clinical trial conducted in 2005, Patchell et al. ${ }^{8}$ demonstrated the superiority of surgical treatment for circumferential spinal decompression, in combination with fixation of the spine in patients with metastatic spinal cord compression by solid tumors when compared to radiotherapy alone. In addition to immediate spinal cord decompression, the surgery would have the advantage of reestablishing the stability of the spine.

Laminectomy without fixation would only be suitable for patients with a stable spine in which the posterior decompression alone was sufficient to obtain decompression. ${ }^{17}$ There is also concern regarding the evolution of the cancer, since it is possible to develop instability along the course of the disease. However, the fixation of the spine is associated with increased operative time, costs, and procedural complications. ${ }^{15}$

A comparison of studies published in the literature regarding the results of surgical treatment of the metastatic disease is difficult. Populations are different with respect to performance, age, staging and origin of the primary tumors that motivated metastasis. $6,7,17,18$ These factors may render populations between different studies incomparable.

In this study, most patients had spinal cord compression due to prostate tumor metastasis as their diagnosis. The prevalence of prostate tumor metastases in this population in which the spine was subjectively judged to be stable by the treatment team is determined by the usual characteristic of the blastic matrix associated with the injury. It is believed that blastic lesions are more stable than those of Iytic matrix. This concept is also used as a factor in SINS for determining stability. ${ }^{13}$

We had no radiological mechanical complications. In this sample, $42.86 \%$ of patients were still alive and at follow-up in the end of the study, so they remain susceptible to the occurrence of instability throughout the progression of the disease.

In this study, the patients included had a limited life expectancy at the time of the indication of surgical treatment according to the classification of Tokuhashi et al., ${ }^{16}$ and only one (4.76) had scores indicating more than one year survival. The limited survival and physical performance restrictions may also have contributed to the absence of a negative outcome in relation to mechanical complications due to the reduction of overload on the spine.

We had 15 perioperative complications. In a prospective study on complications related to instrumentation in spine surgery, 
Campbell et al..$^{15}$ found a $56.4 \%$ rate of perioperative complications. In this study, the risk of complications increases with the number of vertebrae instrumented.

Omeis et al. ${ }^{19}$ found an infection rate of $9.5 \%$ in patients operated for metastatic disease with decompression and instrumented arthrodesis, versus $4.76 \%$ in our study, treated with uninstrumented laminectomy. These results suggest a lower rate of complications with laminectomy alone.

We believe that the unfavorable results of laminectomy without fixation for patients with metastatic spinal cord compression in the literature are more related to the use of the technique in patients with unrecognized instability of the spine. Thus, the worsening of the instability is related to functional deterioration.

In this study, we reassess the stability of the spine through the use of the SINS. According to the SINS, only one patient was classified as having an unstable spine, who underwent laminectomy at seven levels, and even in this case there were no mechanical complications.

Limitations of this study include its retrospective design, the small sample size, and the lack of a control group. Another limitation is the lack of evaluation of quality of life parameters before and after surgery. These data were not collected due to the limited information available in the records studied.

In this study, the absence of mechanical complications in the evolution of patients who underwent laminectomy without fixation, in a group of patients evaluated subjectively to have a stable spine, indicates that laminectomy is still a treatment option that should be considered, especially for those with impaired performance and a limited expectation of survival.

\section{CONCLUSIONS}

Laminectomy alone at one or more levels is a safe procedure for the treatment of metastatic spinal cord compression when there is a judgment that the column is stable at the time of the surgical indication.

All authors declare no potential conflict of interest concerning this article.

\section{REFERENCES}

1. Aaron AD. The management of cancer metastatic to bone. JAMA. 1994;272(15):1206-9.

2. Constans JP, de Divitiis E, Donzelli R, Spaziante R, Meder JF, Haye C. Spinal metastases with neurological manifestations. Review of 600 cases. J Neurosurg. 1983;59(1):111-8.

3. Gasbarrini A, Li H, Cappuccio M, Mirabile L, Paderni S, Terzi S, et al. Efficacy evaluation of a new treatment algorithm for spinal metastases. Spine(Phila Pa 1976). 2010;35(15):1466-70.

4. Bilsky MH, Lis E, Raizer J, Lee H, Boland P. The diagnosis and treatment of metastatic spinal tumor. Oncologist. 1999;4(6):459-69.

5. Harrington KD. Orthopedic surgical management of skeletal complications of malignancy. Cancer. 1997;80(Suppl 8):1614-27.

6. Wise JJ, Fischgrund JS, Herkowitz HN, Montgomery D, Kurz LT. Complication, survival rates, and risk factors of surgery for metastatic disease of the spine. Spine (Phila Pa 1976). 1999;24(18):1943-51.

7. Young RF, Post EM, King GA. Treatment of spinal epidural metastases. Randomized prospective comparison of laminectomy and radiotherapy. J Neurosurg. 1980;53(6):741-8.

8. Patchell RA, Tibbs PA, Regine WF, Payne R, Saris S, Kryscio RJ, et al. Direct decompressive surgical resection in the treatment of spinal cord compression caused by metastatic cancer: a randomised trial. Lancet. 2005;366(9486):643-8.

9. Rades D, Huttenlocher S, Dunst J, Bajrovic A, Karstens JH, Rudat V, et al. Matched pair analysis comparing surgery followed by radiotherapy and radiotherapy alone for metastatic spinal cord compression. J Clin Oncol. 2010;28(22):3597-604.

10. Jacobs WB, Perrin RG. Evaluation and treatment of spinal metastases: na overview. Neurosurg Focus. 2001;11(6):e10.

11. Biermann JS, Holt GE, Lewis VO, Schwartz HS, Yaszemski MJ. Metastatic bone disease: diagnosis, evaluation, and treatment. J Bone Joint Surg Am. 2009;91(6):1518-30.

12. Fourney DR, Frangou EM, Ryken TC, Dipaola CP, Shaffrey Cl, Berven SH, et al. Spinal instability neoplastic score: an analysis of reliability and validity from the spine oncology study group. J Clin Oncol. 2011;29(22):3072-7

13. Fisher CG, DiPaola CP, Ryken TC, Bilsky MH, Shaffrey $\mathrm{Cl}$, Berven $\mathrm{SH}$, et al. A nove classification system for spinal instability in neoplastic disease: an evidence-based approach and expert consensus from the Spine Oncology Study Group. Spine. 2010;35(22):E1221-9.

14. Teixeira WG, Coutinho PR, Marchese LD, Narazaki DK, Cristante AF, Teixeira MJ, et al. Interobserver agreement for the spine instability neoplastic score varies according to the experience of the evaluator. Clinics (Sao Paulo). 2013;68(2):213-8.

15. Campbell PG, Yadla S, Malone J, Maltenfort MG, Harrop JS, Sharan AD, et al. Complications related to instrumentation in spine surgery: a prospective analysis. Neurosurg Focus. 2011;31(4):E10

16. Tokuhashi Y, Matsuzaki H, Oda H, Oshima M, Ryu J. A revised scoring system for preoperative evaluation of metastatic spine tumor prognosis. Spine (Phila Pa 1976). 2005;30(19):2186-91

17. White AP, Kwon BK, Lindskog DM, Friedlaender GE, Grauer JN. Metastatic disease of the spine. J Am Acad Orthop Surg. 2006;14(11):587-98.

18. Quan GM, Vital JM, Pointillart V. Outcomes of palliative surgery in metastatic disease of the cervical and cervicothoracic spine. J Neurosurg Spine. 2011;14(5):612-8.

19. Omeis IA, Dhir M, Sciubba DM, Gottfried ON, McGirt MJ, Attenello FJ et al. Postoperative surgical site infections in patients undergoing spinal tumor surgery: incidence and risk factors. Spine (Phila Pa 1976). 2011;36(17):1410-9 